. CE NDDOE/OR/01-1537\&D1

JAN 291397

OSTI

ORNL/M- 5816

\title{
Design/Installation and Structural Integrity Assessment of the Bethel Valley Low-Level Waste Collection and Transfer System Upgrade for Building 3544 \\ (Process Waste Treatment Plant) at Oak Ridge National Laboratory, Oak Ridge, Tennessee
}

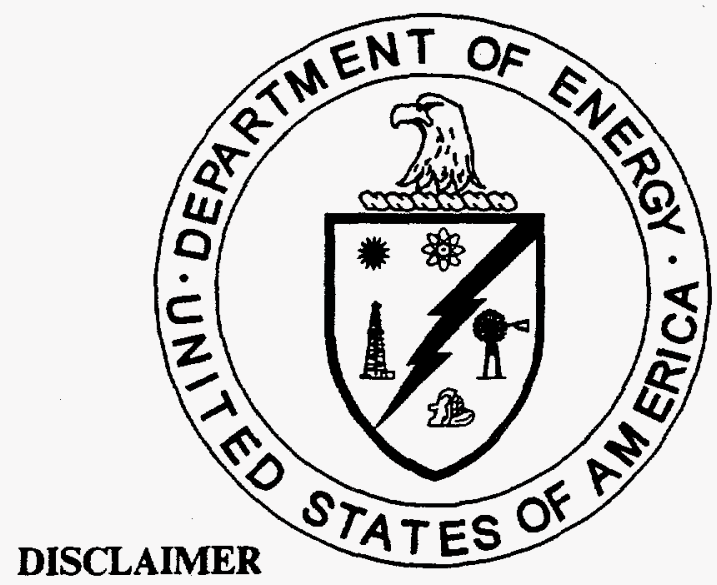

This report was prepared as an account of work sponsored by an agency of the United States Government. Neither the United States Gnvernment nor any agency thereof, nor any of their empleyees, makes any warranty, express or implied, or assumes any legal liability or responsibility for the accuracy, completeness, or usefulness of any information, apparatus, product, or process disclosed, or represents that its use would not infringe privately owned rights. Reference herein to any specific commercial product, process, or service by trade name, trademark, manufacturer, or otherwise does not necessarily constitute or imply its endorsement, recommendation, or favoring by the United States Government or any agency thereof. The views and opinions of authors expressed herein do not necessarily state or reflect those of the United States Government or any agency thereof.

\section{MASTER}

This document has been approved by the ORNL Technical Information Office for release to the public. Date: $12 / 17 / 96$

RSTFIEUTIOH OF THS DOORENT IS UNLMITED

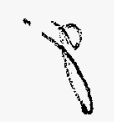




\section{Gilbert/Commonwealth, Inc.}

contributed to the preparation of this document and should not be considered an eligible contractor for its review. 
Energy Systems Environmental Restoration Program

\author{
Design/Installation and Structural Integrity Assessment \\ of the Bethel Valley Low-Level Waste Collection and \\ Transfer System Upgrade for Building 3544 \\ (Process Waste Treatment Plant) \\ at Oak Ridge National Laboratory, \\ Oak Ridge, Tennessee
}

Date Issued-December 1996

\author{
Prepared by \\ Gilbert/Commonwealth, Inc. \\ Oak Ridge, Tennessee \\ under subcontract 32X-GJF75C

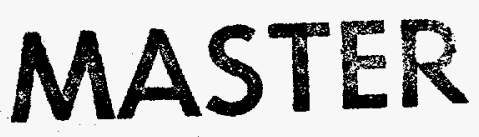 \\ Prepared for the \\ U.S. Department of Energy \\ Office of Environmental Management \\ under budget and reporting code EW 20 \\ Environmental Management Activities at the \\ OAK RIDGE NATIONAL LABORATORY \\ Oak Ridge, Tennessee 37831 \\ managed by \\ LOCKHEED MARTIN ENERGY SYSTEMS, INC. \\ for the \\ U.S. DEPARTMENT OF ENERGY \\ under contract DE-AC05-84OR21400
}




\section{PREFACE}

This document presents the planned modifications to Building 3544, Process Waste Treatment Plant, at Oak Ridge National Laboratory. The modifications are in response to the Federal Facility Agreement relating to environmental protection requirements for tank systems. The work is being performed under Work Breakdown Structure 1.3.6.4.14.5 (Activity Data Sheet 3206). 


\section{DISCLAIMER}

Portions of this document may be illegible in electronic image products. Images are produced from the best available original document. 


\section{DISCLAIMER}

This report was prepared as an account of work sponsored by an agency of the United States Government. Neither the United States Government nor any agency thereof, nor any of their employees, make any warranty, express or implied, or assumes any legal liability or responsibility for the accuracy, completeness, or usefulness of any information, apparatus, product, or process disclosed, or represents that its use would not infringe privately owned rights. Reference herein to any specific commercial product, process, or service by trade name, trademark, manufacturer, or otherwise does not necessarily constitute or imply its endorsement, recommendation, or favoring by the United States Government or any agency thereof. The views and opinions of authors expressed herein do not necessarily state or reflect those of the United States Government or any agency thereof. 


\section{CONTENTS}

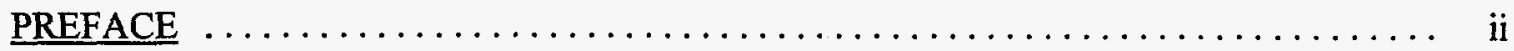

EXECUTIVE SUMMARY $\ldots \ldots \ldots \ldots \ldots \ldots \ldots \ldots \ldots \ldots \ldots \ldots \ldots \ldots \ldots \ldots \ldots \ldots \ldots \ldots$

I. INTRODUCTION $\ldots \ldots \ldots \ldots \ldots \ldots \ldots \ldots \ldots \ldots \ldots \ldots \ldots \ldots \ldots \ldots \ldots \ldots$

II. DESCRIPTION OF PROJECT $\ldots \ldots \ldots \ldots \ldots \ldots \ldots \ldots \ldots \ldots \ldots \ldots \ldots \ldots \ldots \ldots \ldots \ldots \ldots$

III. PURPOSE OF PROJECT $\ldots \ldots \ldots \ldots \ldots \ldots \ldots \ldots \ldots \ldots \ldots \ldots \ldots \ldots \ldots \ldots \ldots \ldots \ldots \ldots$

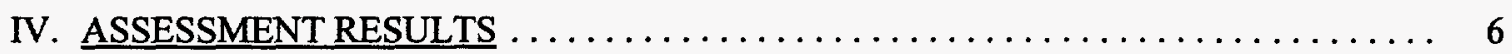

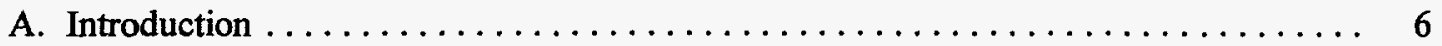

B. Standards for Design/Installation of New or Replacement Transfer System . . . . . 10

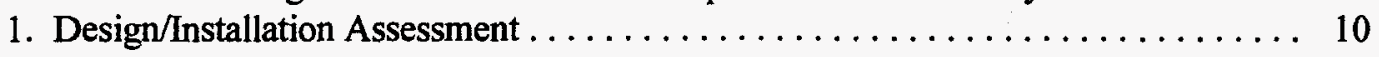

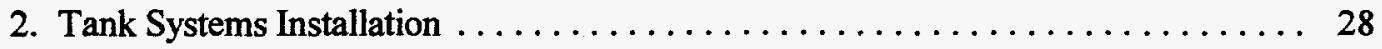

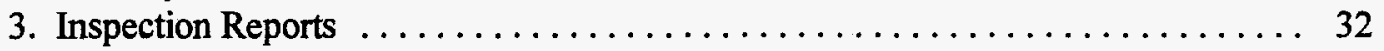

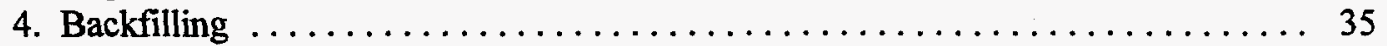

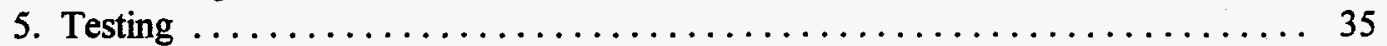

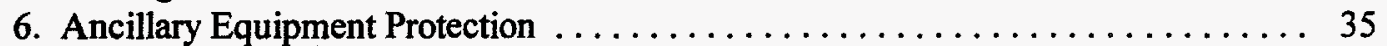

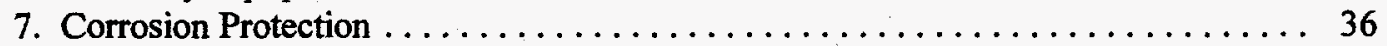

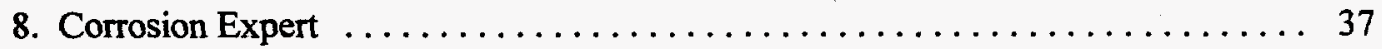

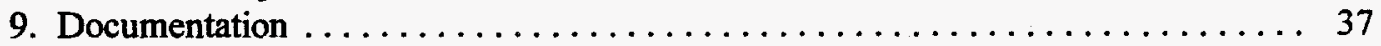

C. Standards for Containment/Release Detection $\ldots \ldots \ldots \ldots \ldots \ldots \ldots \ldots \ldots \ldots \ldots$

1. Secondary Containment Systems Requirements ................ 40

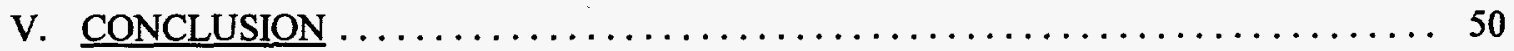




\section{EXECUTIVE SUMMARY}

This document describes and assesses planned modifications to be made to the Building 3544 Process Waste Treatment Plant of the Oak Ridge National Laboratory, Oak Ridge, Tennessee. The modifications are made in response to the requirements of the Federal Facility Agreement (FFA) relating to environmental protection requirements for tank systems.

The modifications include the provision of a new double contained LLW line replacing an existing buried line that does not provide double containment. This new above ground, double contained pipeline is provided to permit discharge of treated process waste fluid to an outside truck loading station. The new double contained discharge line is provided with leak detection and provisions to remove accumulated liquid. An existing LLW transfer pump, concentrated waste tank, piping and accessories are being utilized, with the addition of a secondary containment system comprised of a dike, a chemically resistant internal coating on the diked area surfaces and operator surveillance on a daily basis for the diked area leak detection.

This assessment concludes that the planned modifications comply with applicable requirements of Federal Facility Agreement, Docket No. 89-04-FF, coveiniti tive Oak Ridge Reservation.

A formal design certification statement is included herein on Page 38; a certification covering the installation shall be executed prior to placing the modified facility into service.

Certified by: Harvey N. Goldstein, P.E.

Directive Engineer

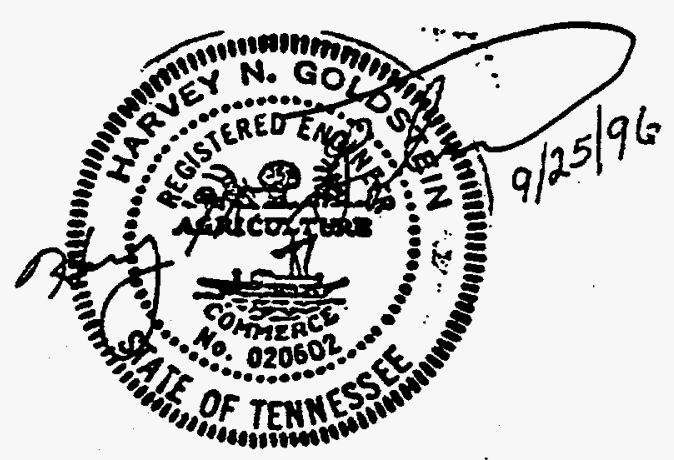




\section{INTRODUCTION}

This document presents a Design/Installation and Structural Integrity Assessment for a replacement transfer line for portions of the Bethel Valley Low Level Waste (LLW) System, located at the Oak Ridge Reservation, Oak Ridge, Tennessee. This issue of the assessment covers the design aspects of the replacement transfer line, and certifies that the design has sufficient structural integrity and is acceptable for the storing or treating of hazardous and/or radioactive substances.

This document will be reissued at a future date and will then include the assessment of the installation of the replacement transfer line. The present issue identifies specific activities that must be completed during the fabrication, installation, and testing of the replacement transfer line in order to provide assurance that the final installation complies with the applicable requirements of the Federal Facility Agreement, Docket No. 89-04-FF, covering the Oak Ridge Reservation.

The assessment presented in this document is responsive to the Federal Facility Agreement for the Oak Ridge Reservation. 


\section{DESCRIPTION OF PROJECT}

The LLW system at Oak Ridge National Laboratory (ORNL) consists of facilities to collect, transfer, concentrate, and store aqueous radioactive waste solutions from various sources at the Laboratory. The system is designed to accommodate waste solutions having an activity content as high as $5 \mathrm{Ci} / g a l$. The collection and transfer system consists of an extensive network of underground piping, valve boxes, and collection tanks. It allows for collection of LLW from the various source facilities and periodic transfer through the Central Waste Collection Header (CWCH) to the storage tanks serving the Laboratory's central LLW evaporator. Status of various system operations is centrally monitored at the Laboratory's Waste Operations Control Center (WOCC). Wastes are concentrated at the evaporator, and the concentrate is collected in a local storage tank and periodically transferred to tanks located in the Melton Valley area of the Laboratory for ultimate storage.

The Exhibit II-1 presents a map of a portion of the Bethel Valley complex, showing all of the facilities, existing and new, that comprise the entire scope of the Bethel Valley LLW Upgrade Project. This assessment report pertains to the modifications to be made to the existing Process Waste Treatment Plant (Building 3544) to achieve compliance with the Federal Facility Agreement. This includes the provision of a new LLW transfer line from the existing concentrated waste tank to a tanker truck loading station outside building 3544 . The concentrated waste tank ( $L-11)$ serves as a process collection tank. These wastes may include a variety of dilute acids, bases and organics. Due to the nature of the tank contents, the LLW transfer line is designed, fabricated, installed, and inspected in a manner consistent with the requirements that would apply to a LLW tank system, to the extent feasible. The tank contents are treated as LLW upon discharge from the tank into the discharge line to the loading arm at the truck transfer station. The discharge line is classified as a LLW line. A more detailed description of the modifications to this facility are described in Sections III and IV of this assessment.

The limits of the probable maximum flood due to extreme flood stage for White Oak Creek is superimposed on the map in Exhibit II-1. As may be noted, site flooding from this type of phenomena is a credible event for the Building 3544 portion of the upgrade. The assessment considers a 2,000 year flood where the flood elevation is estimated to be 785 feet which would submerse a portion of the concentrated waste tank and a portion of the transfer LLW piping. 


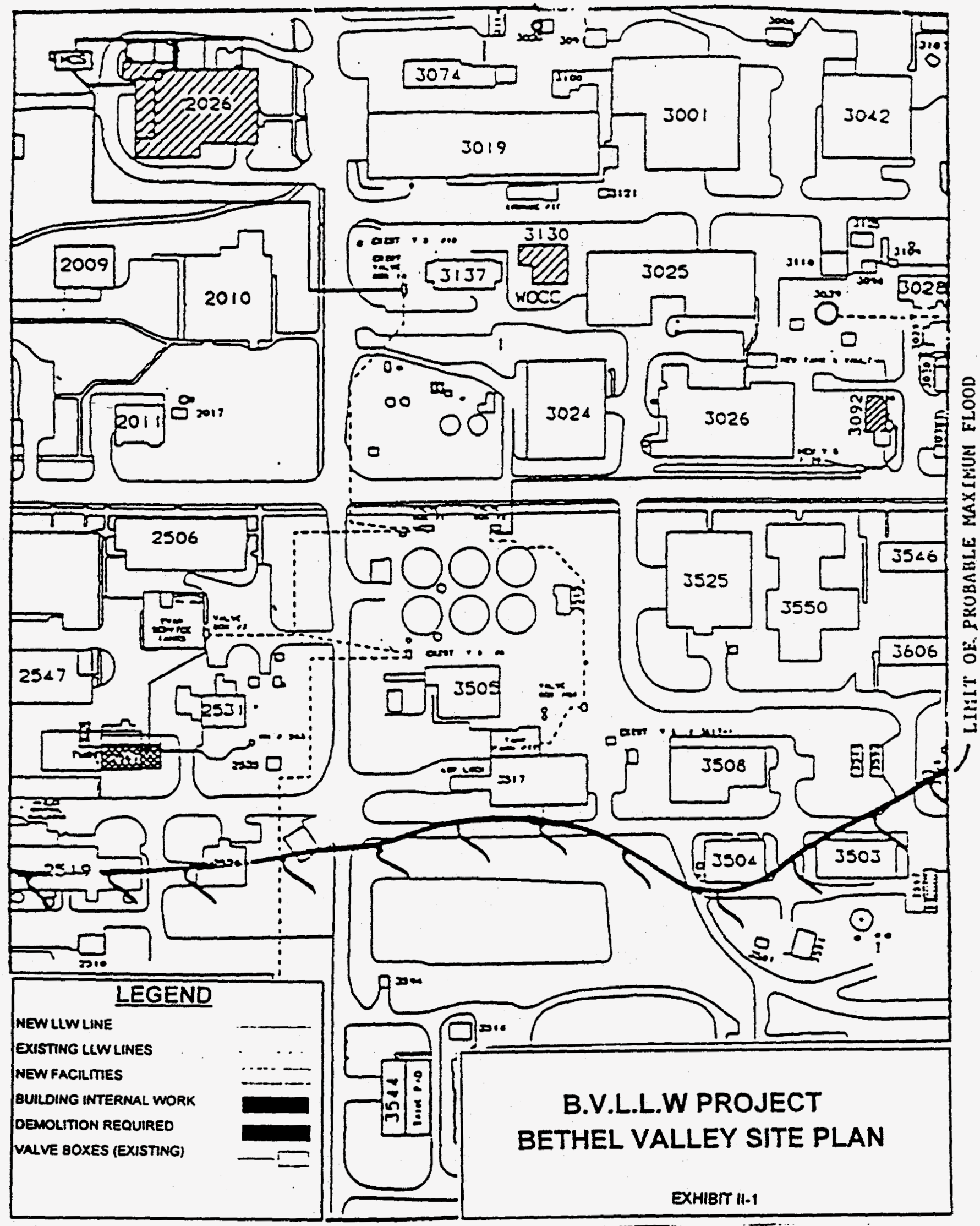


Portions of the LLW system are several decades old, or older, and do not comply with current environmental protection regulations. Several subsystems of the LLW system have been designated to receive replacement and refurbishment. One such subsystem serves Building 3544, the Process Waste Treatment Plant. This assessment focuses on the scope of work for the Building 3544 replacement LLW Collection and Transfer System. which is comprised of the following:

- Provision for modification to the secondary containment consisting of adding a stainless steel dike around the existing concentrated waste tank $(L-11)$ and the existing transfer pump (L-11-P). The diked area will have a minimum capacity of 500 gal. The existing facility is equipped with a floor drain which is routed to a stainless steel lined sump. The new diked area provides secondary containment for the existing tank, and includes a low point drain which will be normally plugged pending waste characterization. Direct operator surveillance on a daily basis will be utilized for leak detection in the diked area. There is a tank level monitor mounted on the tank. Any spill will be contained within the diked area. Removal of accumulated liquid will be through the floor drain and associated sump upon characterization. The existing tank serves as a process collection reservoir for evaporator bottoms from the L-10 PWTP Evaporator.

- Provision for the addition of a chemical resistant coating to the diked secondary containment area. The coating shall be resistant to chemical spills of $60 \%$ Nitric acid, concentrated Sulfuric acid and $40 \% \mathrm{NaOH}$.

- $\quad$ Provisions to add a new double contained LLW line that connects to the discharge of the existing transfer pump and extends to a loading arm apparatus mounted outside Building 3544 on the northeast end of the tank pad adjacent to the truck loading station.

- Provisions to add a loading arm to facilitate the transfer of treated process waste from the new LLW double contained line to the various LLW transfer trucks.

- For the purpose of this assessment, the following terms are defined:

- Tank is defined as the existing tank provided in the new diked secondary containment; this term is limited to the tank proper and excludes the tank vault, chemical resistant liners, and other design features.

- Tank System is defined as the entire fluid retaining system for process fluid from the concentrated waste tank and vault, the sump, the existing transfer pump, and the pump discharge lines to the tie-in to the new double contained pipe to the loading arm.

- $\quad$ Primary Fluid Boundary is defined as piping containing the treated process waste or the LLW, including single wall piping within buildings, the inner pipe in double wall pipe runs, and the new loading arm. 
- Secondary Containment is defined as the outer pipe in double wall pipe runs and the reinforced concrete diked area, with an inner protective coating as a liner.

- Support Equipment is defined as, but not necessarily limited to, equipment required for system functional capability, such as sump level instrumentation, associated piping and valves, and the transfer pump. 


\section{ASSESSMENT RESULTS}

\section{A. Introduction}

This assessment covers the modification to the LLW Collection and Transfer System designed for installation to serve Building 3544, the Process Waste Treatment Plant, and the new transfer line connecting Building 3544 with the new loading arm.

This assessment reviews the design of the replacement Tank System for the above described Building 3544 facility (Section IV.B). The assessment also covers the secondary containment provisions and ancillary equipment associated with the Building 3544 facility (Section IV.C). Simplified diagrams illustrating the schematic and physical aspects of this subsystem are shown in Exhibits IV-I, IV-2, and IV-3.

Several design conditions are presented for evaluation, as follows:

- $\quad$ Single wall pipe routed within the facility, where the pipe is visible for routine (i.e., daily) visual inspection to detect leakage. Potential leakage from flanged connections, valve stems, and pump seals is limited to small amounts of fluid that would be detected by routine observations. This condition is manifested in limited portions of the existing Building 3544 facility where tie-ins are made to the discharge of the transfer pump. A major spill from the single wall piping is considered extremely unlikely, due to the stringent design measures taken for this facility. These include high grade, corrosion resistant materials, and design to a low hazard classification, with seismic and other loads evaluated.

- Single wall pipe routed at and adjacent to the loading arm. This piping contains LLW only during transfer operations, during which time the piping is under the direct and continuous surveillance of the operator who is provided with a switch that can immediately terminate pumping operation. Potential leaks or spills are contained by the truck loading station, which is provided with a chemical resistant coating.

- Double wall pipe routed aboveground from the tie in to the existing transfer pump discharge piping to the loading arm located outside Building 3544 . The outer pipe fulfills the secondary containment function and is protected from corrosion through the material selection. The annular space between the double wall pipe retains potential leakage from the inner, primary, waste containing pipe. The space is provided with leak detection capability by pressurization with nitrogen and monitoring of the annular space pressure. 


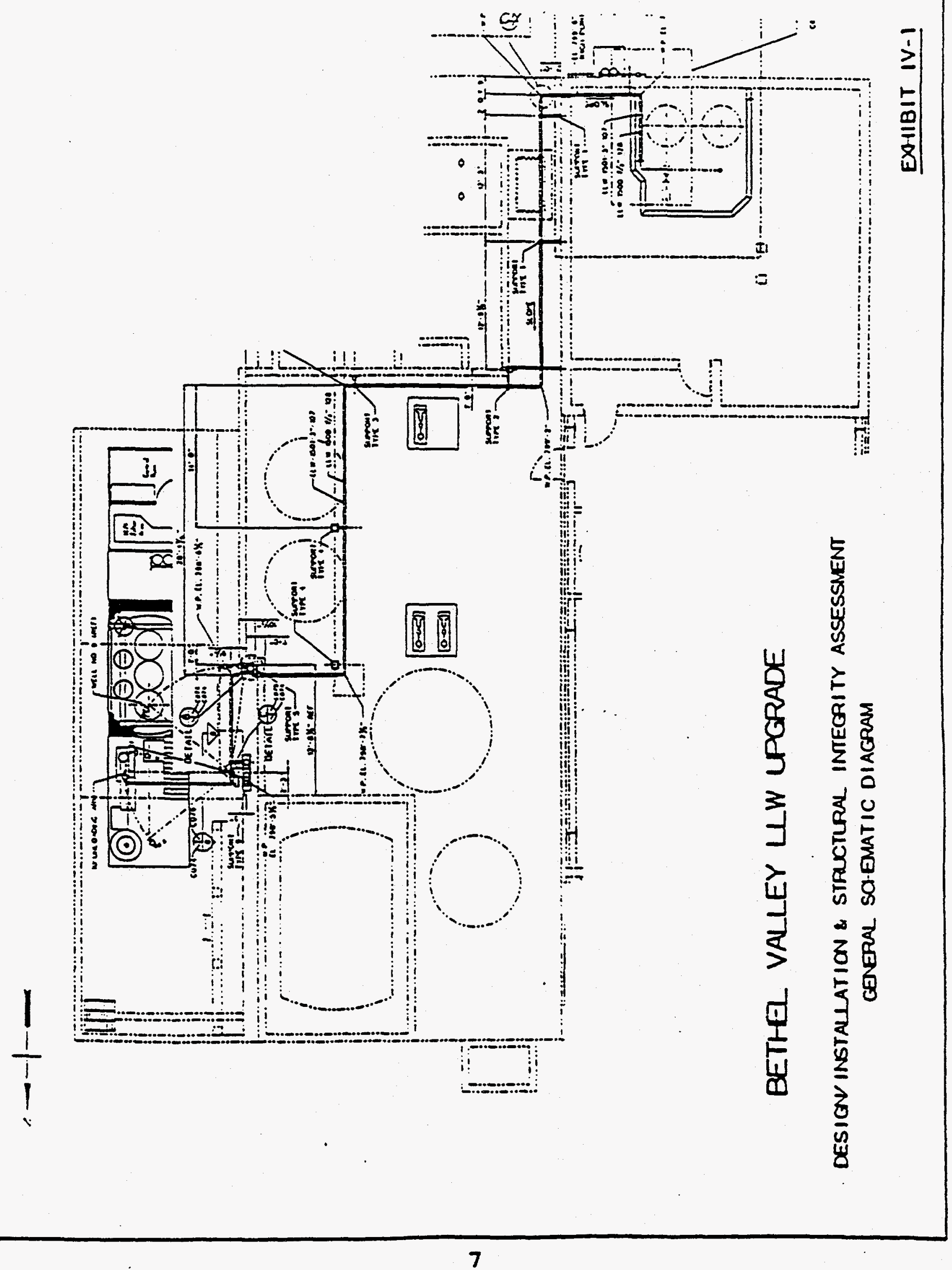




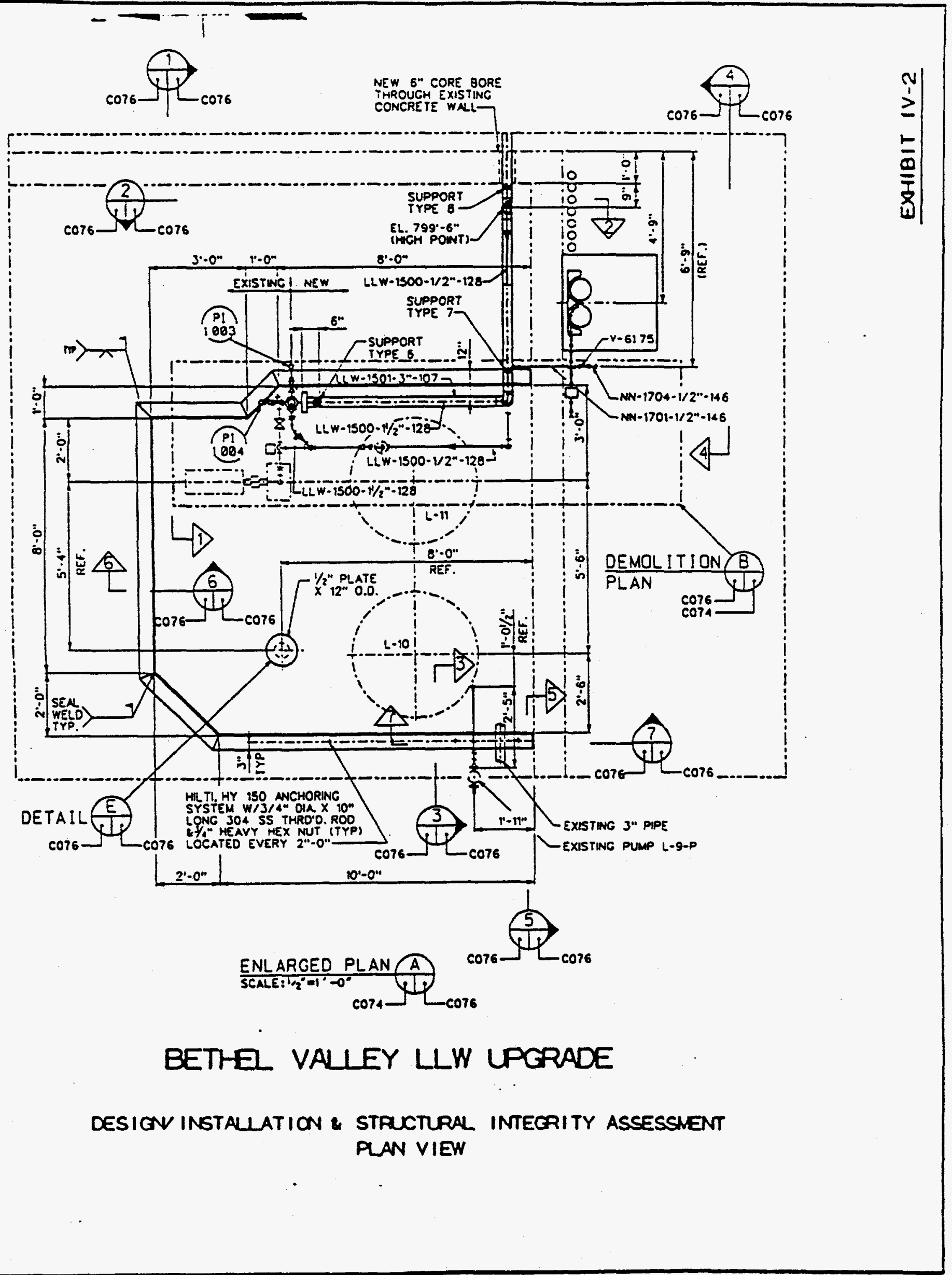




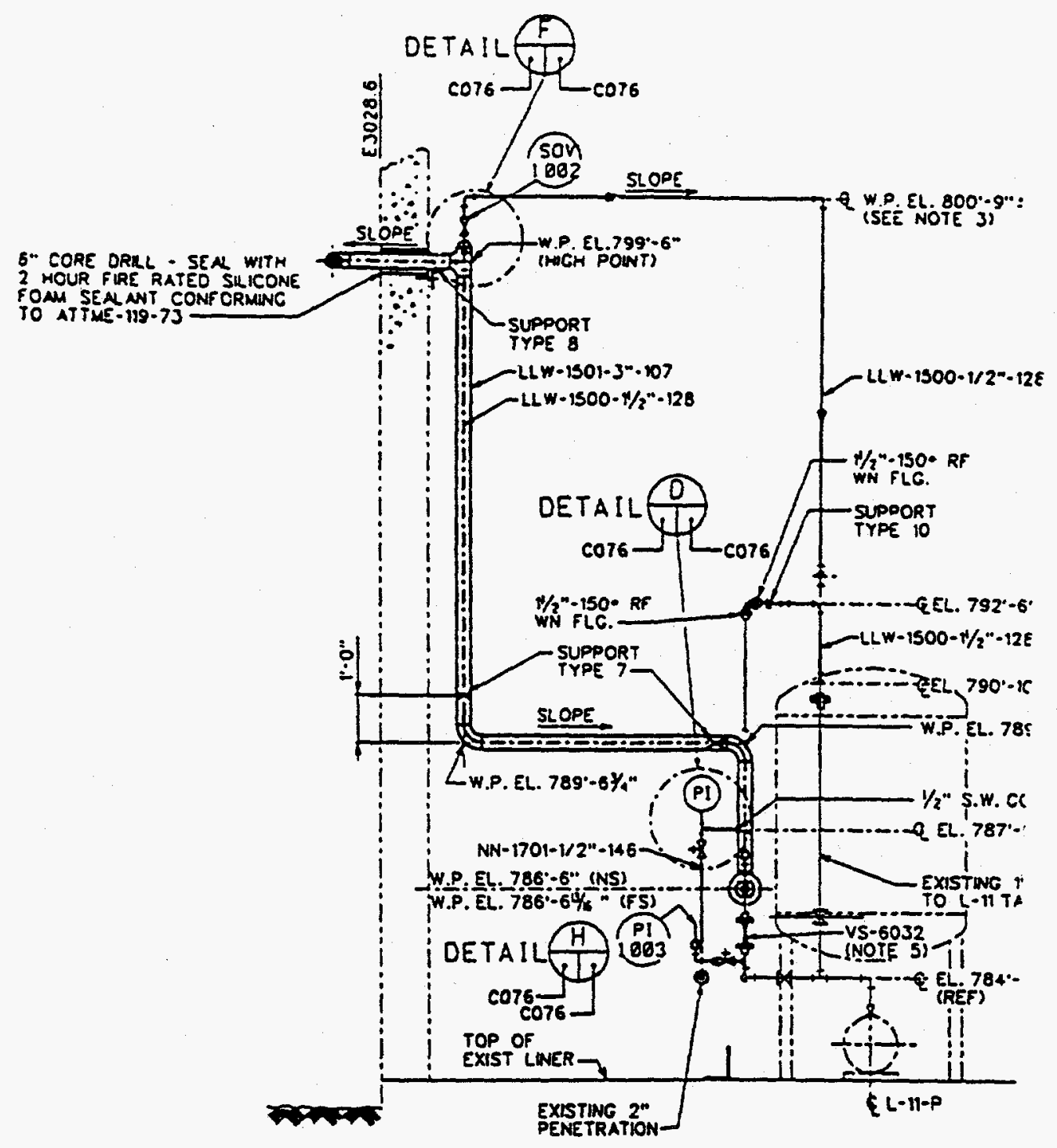

BETHEL VALLEY LLW LPGRADE

DESIGV INSTALLATION \& STRLCTURAL INTEGRITY ASSESSMENT CROSS-SECTION THROUOH VALTED STRUCTRES SHOWINO ESSENTIAL FEATLPES OF PRIMAPY ANO SECONOAPY FLUID CONTAIMENT 
- A tank comprising a single wall process fluid holding and collection tank fabricated from corrosion resistant material and located in an above grade reinforced concrete vault containing a diked area. The diked area, which fulfills the secondary containment function, is provided with a chemical resistant liner. The plug in the floor drain in the diked area prevents any leaked or spilled liquids from entering the sump and activating the existing level detector. The diked area is under continuous surveillance by the operator when the building is occupied, permitting visual detection of leaks or spills. The dike is designed to withstand design basis natural phenomena, including seismic events and straight winds. Tornadoes are not a design basis event for this building.

The overall conclusion of this assessment is that the various elements described above, which comprise the modifications to the Building 3544 facility, are in compliance with applicable portions of Appendix F to the Federal Facility Agreement. However, should the facility be unoccupied for any period of time, in excess of 24 hours, a level detector should be provided within the diked area to provide notification that a leak or spill has occurred. The remaining portions. of this assessment describe the means of compliance for each design feature and confirm the adequacy of the design for the purpose of environmental compliance.

B. Standards for Design/Installation of New or Replacement Transfer System

1. Design/Installation Assessment

This part of the assessment focuses on the following aspects of the replacement transfer system:

- $\quad$ Design standards, including codes, criteria, and specifications used by the design project for design, fabrication, and installation of the transfer system.

- Characteristics of hazardous substances to be contained by the transfer system.

Corrosion protection.

Man-induced hazards, such as vehicular traffic.

Natural phenomena, such as seismic events, frost heave, ground water, heavy rain and surface run-off, and potential flooding of nearby water sources (White Oak Creek). 
(a) Design Standards

The applicable standards, codes, and criteria used by the design project that govern the design, fabrication, and installation of the transfer system are identified herein. The application of standards, codes, and criteria is generally performed on an engineering disciplinary basis and, therefore, the following listing is so organized. The list has been edited to minimize duplication, but certain entries are repeated if they constitute a key element in the input for a particular discipline work scope. The adequacy of these standards, codes, and criteria is evaluated by discipline and is correlated with specific design features when applicable.

(i) Mechanical Engineering and Design

The scope of mechanical engineering and design for the transfer system includes the waste concentration tank, all LLW containing piping (single and double wall), and process support equipment such as the transfer pump.

The assessment concludes that the standards, codes, criteria, and specifications for the mechanical engineering aspects of the transfer system for the Building 3544 Process Waste Treatment Plant, are suitable and appropriate. The tank, primary and secondary piping, and other design elements are covered by codes, etc. that mandate use of appropriate materials, design, fabrication and installation, and examination and inspection procedures and techniques.

The selection of materials for the LLW Transfer System is appropriate in order to assure compatibility with the process solution to be stored and transferred. The concentrated waste tank in Building 3544 contains a nominal five hundred gallons of dilute acids, bases and organics. The residence time for acids is low. After each waste transfer, the concentrated waste tank (Tank L-11) is neutralized with a high $\mathrm{pH}$ solution and flushed with water. The material selected for principal portions of the primary, or inner, boundary of the new piping is Type 304L stainless steel, which exhibits excellent corrosion resistance.

The existing concentrated waste tank is also constructed of Type 304L austenitic stainless steel.

Related support equipment such as the transfer pump, and the diked liners are also fabricated from chemical resistant materials. The type of material selected is considered to be compatible with the wastes to which it will be exposed. 
This portion of the assessment is valid for the design and installation of the transfer system. The design is essentially complete and is in compliance with the referenced codes, standards, and criteria. During the installation phase of the project, actions such as examinations, inspections, and tests must be undertaken to confirm that the installation remains in conformance with the design and with required codes,

standards, etc.

The application of the following standards, codes, and criteria to essential elements of the design is indicated as follows:

P - applies to primary (inner) LLW containing pipe and valves

S - $\quad$ applies to secondary (outer) pipe

\section{Codes}

American Society of Mechanical Engineers (ASME)

- Boiler and Pressure Vessel Code Section

II, Material Specifications (Governs materials specifications in conjunction with ASTM Standards)

- Section III, Nuclear Power Plant Components Division 1, Subsection NB (Used to govern procurement of piping materials)

- Section V, Non-destructive Examination (Governs non-destructive examination in conjunction with Section VIII)

- $\quad$ Section IX, Welding and Brazing Qualifications (Governs qualification of welders)

American National Standards Institute (ANSI)

- B 16.5, Steel Pipe Flanges and Flanged Fittings (Governs flange pressure/temperature ratings) 
- $\quad$ B 31.3, Chemical Plant and Petroleum

P,S Refinery Piping (Design code for LLW piping)

\section{$\underline{\text { Standards }}$}

American Society for Testing Materials (ASTM)

- A-182, Specification for Forged or Rolled

P,S Alloy-Steel Pipe Flanges, Forged Fittings, and Valves and Parts for High

Temperature Service

- A-193, Specification for Alloy-Steel and Stainless Steel Bolting Materials for High Temperature Service

- A-194, Specification for Carbon and

$P, S$ Alloy-Steel Nuts for Bolts for High Pressure and High Temperature Service

- A-213, Specification for Seamless Ferritic and Austenitic Alloy-Steel Boiler-Superheater and Heat Exchanger Tubes

- A-262, Practices for Detecting Susceptibility to Intergranular Attack on Austenitic Stainless Steels

- A-312, Specification for Seamless and Welded Austenitic Chromium-Nickel Alloy Steel Pipe for High Temperature Service

- A-358, Specification for Electric-Fusion-Welded Austenitic Chromium-Nickel Alloy Steel Pipe for High Temperature Service

- A-403, Specification for Wrought $P, S$ Austenitic Stainless Steel Piping Fittings 
- A5.9, Specification for Corrosion Resisting Chromium and Chromium-Nickel Steel Bare and Composite Metal Cored and Stranded Welding Electrodes and Welding Rods

- QC-1,Standard for AWS Certification of P,S Welding Inspectors

- SNT-TC-1A, Recommended Practice, American Society for Non-destructive Testing, Inc.

Other

- Occupational Safety and Health Administration Standards (OSHA)

(ii) Structural Engineering and Design

The scope of structural engineering and design includes the lined, diked structure providing secondary containment for the existing concentrated waste tank. This diked area is within an above ground tank vault.

The new diked area consists of a stainless steel barrier plate attached to the existing tank vault floor slab and surrounds the existing concentrated waste tank and associated transfer pump. The interior dimensions of the diked area are approximately 12 $\mathrm{ft} . x 11 \mathrm{ft}$. in plan by $8 \mathrm{in}$. high with a minimum capacity of 500 gallons. The floor of the tank vault is above ground and is 8 " thick reinforced concrete slab which was designed with a 28 day compressive strength of 4000 psi. The vault is furnished with a sump that is lined with stainless steel providing an additional secondary containment capacity of approximately 1150 gallons compared to the nominal 500 gallon tank capacity. 
The use of the American Concrete Institute codes and standards for design and construction of the existing tank vault concrete structures has been evaluated. Use of these codes and standards will assure high quality concrete structures consistent with the function of housing containment tanks and piping containing liquid process solutions.

The loads and load combinations required by the Uniform Building Code and ANSI A58.1 are appropriate for the design of the concrete structures.

The new chemical resistant liner to be provided on the internal dike surfaces will function as a leak intermediate barrier to facilitate waste characterization. The secondary containment barrier is considered to be the existing tank vault and sump. The thin liner applied to the diked area is relatively flexible compared to the heavy, reinforced concrete floor and dike structures backing the liner. Any minor stresses introduced into the liner through strain compatibility with the concrete structures are minor and self-limiting in nature. The primary design considerations for the chemical resistant liner are material selection and the installation/inspection criteria. The specifications that have been used are appropriate and will result in the required quality to assure leak-tightness.

The following standards, codes, and criteria were applied to assessment and the structural design and specifications for fabrication and installation of the upgrade structural systems.

- Uniform Building Code 1991

- Uniform Building Code 1973 learthquake regulations for existing vault)

- American Concrete Institute 
ACl 318-83 (Revised 1989), "Building Code Requirements for Reinforced Concrete"

$\mathrm{ACl}$ 318-71, "Building Code

Requirements for Reinforced Concrete" (existing tank vault)

ACl 301-84 (Revised 1989),

"Specifications for Structural Concrete for Buildings"

$\mathrm{ACl}$ 309R-87, "Guide for Consolidation of Concrete"

ACl 117-90, "Standard Tolerances for Concrete Structures for Concrete Construction and Materials"

ACl 318-89, "Building Code

Requirements for Reinforced Concrete"

$\mathrm{ACl}$ 315-80, "Details and Detailing of Concrete Reinforcement"

ACl 347-89, "Recommended Practice for Concrete Formwork"

$\mathrm{ACl}$ 304.2, "Placing Concrete By Pumping Methods"

$\mathrm{ACl}$ 308-92, "Standard Practice for Curing Concrete"

ACl 311.4R-88, "Guide for Concrete Inspection"

- $\quad A C l$ 311.5R-88, "Batch Plant Inspection and Field Testing of ReadyMixed Concrete"

- $\quad \mathrm{ACl}$ 305-91, "Hot Weather Concreting" 
ACl 306.1-90, "Cold Weather Concreting"

- American Society For Testing Materials (ASTM) Standards

The quality and testing of materials used in the construction was addressed by reference to the appropriate ASTM standard specifications in the project specifications and by reference in project specifications to governing standards such as $\mathrm{ACl} 318$ or $\mathrm{ACl}$ 301, which incorporate the applicable ASTM standard specifications.

- American Welding Society Specifications and Codes

- D1.1-88, "Structural Welding Code"

- D1.3-81, "Specification for Welding Sheet Steel in Structures"

- American Society of Mechanical Engineers Boiler and Pressure Vessel Code, 1986, including 1987 Addenda

- Section V, "Non-Destructive Examination"

- Section IX, "Qualifications Standard for Welding and Brazing Procedures, Welders, Brazers, and Welding and Brazing Operations"

- Occupational Safety and Health Administration (OSHA) Regulations

- DOE Order 6430.1A, "General Design Criteria" 
- $\quad$ Concrete Reinforcing Steel Institute MSP-1-86, "Manual of Standard Practice," 24th Edition

(iii) Civil/Geotechnical Design Standards

The scope of civil/geotechnical engineering and design includes paving and the evaluation of site soil properties for interfacing with the vehicular surcharge placed on the existing truck loading bay.

The following listing presents standards, codes, and criteria that governed the civil and geotechnical engineering and design for the Bethel Valley LLW Upgrade Project. These standards, codes, and criteria provide a conservative basis for design and installation of the transfer system, and provide assurance that loadings and stresses imposed upon the new and existing components will not cause collapse, rupture, or failure of these design features.

- ORNL/MMES/USDOE "Design Criteria for the Bethel Valley Liquid Low Level Waste Collection and Transfer System Upgrade Project," issued approved September, 1988

- Subsurface soil and rock conditions and the groundwater level are based on information obtained from the following sources:

Logs of borings No. 25 through 29, 31 through 35,37 through 40 , and 111 drilled in 1988.

- information on borings PB-6, PB-8, PB-10, SB-7 and SB-8 drilled during Conceptual Phase Drilling Program, provided by MMES (D. C. Haberkost) through letter dated September 8 , 1988.

Rock surface data on Union Carbide Nuclear Corporation drawings number D36313 and D36314. 
- Laboratory soil test data in EDGe report titled "Proposed Bethel Valley Low Level Waste Project," dated June 22, 1988.

- $\quad$ LMES Technical Specifications and Sample Specifications

- LMES Engineering Standards

- Civil/Geotechnical Construction/Installation Standards (i.e., Interface Procedures):

- Tennessee Department of Transportation "Standard Specifications for Road and Bridge Construction," March 1, 1981, with revisions and additions

- U. S. Department of Labor, Occupational Safety and Health Administration (OSHA) Standards, 29CFR 1926/1910, 1987

(iv) Instruments and Controls Engineering and Design

The codes and standards listed below cover selected aspects of the instruments and controls scope of work for the Building 3544 portion of the Bethel Valley LLW Upgrade. These codes and standards are appropriate and adequate to govern the design and installation of design features necessary for compliance with the Federal Facility Agreement. These design features comprise the level detection and leak detection provisions for the concentrated waste tank, secondary containment vault sumps, and the annular spaces in double wall piping.

\section{Codes}

National Fire Protection Association (NFPA)

- NFPA 70-1990, National Electric Code (NEC) 
American Welding Society (AWS)

- D1.3.81, Structural Welding Code - Sheet Steel

- D1.1.88, Structural Welding Code

\section{Standards}

American National Standards Institute (ANSI)

- B16.1 1-80, Fittings, Socket-Welded, and Threaded

- B31.3-87, Chemical Plant and Petroleum Refinery Piping

- $\quad$ C2, National Electrical Safety Code

Instrument Society of America (ISA)

- ISA-S5.1-1984, Instrumentation Symbols and Identification

- $\quad$ ISA-S5.4-1976 (R-81), Instrument Loop Diagrams

- ISA-RP7.1-1956, Pneumatic Control Circuit Pressure Test

- ISA-S12.13-1986, Performance Requirements, Combustible Gas Detectors

- ISA-S20-1981, Specification Forms for Process Measurement and Control Instrument

- ISA-S51.1-1979, Process Instrumentation National Electrical Manufacturer's Association (NEMA)

- 250-85, Enclosures

- 1CS-6-83, Enclosures for Industrial Controls 
- WC-5, Thermoplastic Insulated Wire and Cable

- WC-7, Cross-linked Thermosetting Polyethylene Insulated Wire and Cable

- WC8, Ethylene-Propylene Rubber Insulated Wire and Cable

(v) Electrical Engineering and Design (Cathodic Corrosion Protection)

Since no tanks or LLW piping are directly in contact with the soil cathodic protection is not required.

\section{IV.B.I(b) Hazardous Substance Characteristics}

The hazardous and/or radioactive substances handled by Building 3544 and transferred from the concentrated waste tank to the loading arm are listed in Table B-1. This characterization is based on assessments of facility mission requirements and historical knowledge of previous waste stream properties, and is provided by Lockheed Martin Energy Systems (ORNL Management and Operations Contractor) as input to this assessment.

It is expected that the waste stream analysis presented in Table B- 1 is representative of the process solutions to be handled by the waste concentration tank in Building 3544 . However, the composition of this waste stream may vary as specific experiments, analyses, and campaigns are conducted. Of principal concern for this assessment is the suitability of the material selected as the primary fluid boundary for piping exposed to unadjusted, undiluted waste. In this regard, the $\mathrm{pH}$ value as a measure of acidity and aggressiveness is of principal interest. The suitability of primary fluid boundary materials is discussed in IV.B.1.(a)(i) of this assessment.

The variations in composition of the waste stream are limited by the General Waste Acceptance Criteria, which specifies activity and concentration limits for waste 
discharged into the LLW system. These criteria are presented below:

\section{Waste Acceptance Criteria}

The LLW system should be used to collect and treat all solutions containing radioactivity above the levels listed in Table B-2, with the following provisions:

- Liquid radioactive wastes added to the LLW system must not have an activity concentration exceeding 5 $\times 10^{10} \mathrm{~Bq} / \mathrm{L}$ (5ci/gal).

- Solutions containing ${ }^{233} \mathrm{U},{ }^{235} \mathrm{U},{ }^{235} \mathrm{Pu}$, or ${ }^{241} \mathrm{Pu}$ must be mixed with depleted uranium or natural thorium so that the resultant solution will contain at least 100 parts by weight of ${ }^{238} \mathrm{U}$ or ${ }^{232} \mathrm{Th}$ per part by weight of the fissile isotope(s).

- Solutions containing TRU isotopes of ${ }^{233} U$ that are added to the LLW system must not have a total specific activity from those nuclides greater than $3.7 \times 10^{6} \mathrm{~Bq} / \mathrm{kg}(100 \mathrm{nCi} / \mathrm{g})$.

- Beta-gamma emitting waste greater than $5 \times 10^{10}$ $\mathrm{Bq} / \mathrm{L}(5 \mathrm{Ci} / \mathrm{gal})$ and high toxicity alpha and TRU waste greater than $3.7 \times 10^{6} \mathrm{~Bq} / \mathrm{kg}(100 \mathrm{nCi} / \mathrm{g})$ must be diluted to levels below those limits prior to discharge.

- Before disposing of liquid waste containing reportable nuclear material, the generator must execute Form UCN-6073 to request and receive permission from the Special Materials Management Department. Reportable quantities of nuclear material are listed in Health Physics Procedure 5.3, page 7, Table 2. The generator prepares Form UCN-2681 to complete the transfer of the reportable nuclear material to either the Liquid and Gaseous Waste Operations Department or the Solid Waste Operations Department. 
Table B-1

BETHEL VALLEY LIQUID LOW LEVEL WASTE

STREAM CHARACTERIZATIONS

BUILDING 3544 - PROCESS WASTE TREATMENT PLANT

Component
Gross Alpha
Gross Beta
$\mathrm{Sr}-90$
$\mathrm{Ag}$
$\mathrm{Al}$
$\mathrm{As}$
$\mathrm{B}$
$\mathrm{Ba}$
$\mathrm{Ca}$
$\mathrm{Cd}$
$\mathrm{Cr}$
$\mathrm{Cu}$
$\mathrm{Fe}$
$\mathrm{Ga}$
$\mathrm{Hf}$
$\mathrm{K}$
$\mathrm{Li}$
$\mathrm{Mg}$
$\mathrm{Mn}$
$\mathrm{Mo}$
$\mathrm{Na}$
$\mathrm{Ni}$
$\mathrm{Nitrate}$
$\mathrm{P}$
$\mathrm{Pb}$
$\mathrm{Sb}$
$\mathrm{Se}$
$\mathrm{Si}$
$\mathrm{Sr}$
$\mathrm{Ti}$
$\mathrm{V}$
$\mathrm{Zn}$

\begin{tabular}{ll}
$\mathrm{Units}$ & \multicolumn{1}{c}{ Value } \\
$\mathrm{Bq} / \mathrm{ml}$ & 20 \\
$\mathrm{~Bq} / \mathrm{ml}$ & 5900 \\
$\mathrm{ug} / \mathrm{ml}$ & $\mathrm{ND}$ \\
$\mathrm{ug} / \mathrm{ml}$ & $<14$ \\
$\mathrm{ug} / \mathrm{ml}$ & 68 \\
$\mathrm{ug} / \mathrm{ml}$ & $<28$ \\
$\mathrm{ug} / \mathrm{ml}$ & $<22$ \\
$\mathrm{ug} / \mathrm{ml}$ & 72 \\
$\mathrm{ug} / \mathrm{ml}$ & 100,000 \\
$\mathrm{ug} / \mathrm{ml}$ & $<1.4$ \\
$\mathrm{ug} / \mathrm{ml}$ & 29 \\
$\mathrm{ug} / \mathrm{ml}$ & 270 \\
$\mathrm{ug} / \mathrm{ml}$ & 99 \\
$\mathrm{ug} / \mathrm{ml}$ & $<83$ \\
$\mathrm{ug} / \mathrm{ml}$ & $\mathrm{ND}$ \\
$\mathrm{ug} / \mathrm{ml}$ & 1800 \\
$\mathrm{ug} / \mathrm{ml}$ & $<55$ \\
$\mathrm{ug} / \mathrm{ml}$ & 21,000 \\
$\mathrm{ug} / \mathrm{ml}$ & 36 \\
$\mathrm{ug} / \mathrm{ml}$ & $<11$ \\
$\mathrm{ug} / \mathrm{ml}$ & 5600 \\
$\mathrm{ug} / \mathrm{ml}$ & 20 \\
$\mathrm{ug} / \mathrm{ml}$ & 690 \\
$\mathrm{ug} / \mathrm{ml}$ & 120 \\
$\mathrm{ug} / \mathrm{ml}$ & $<55$ \\
$\mathrm{ug} / \mathrm{ml}$ & $<55$ \\
$\mathrm{ug} / \mathrm{ml}$ & $<55$ \\
$\mathrm{ug} / \mathrm{ml}$ & $<55$ \\
$\mathrm{ug} / \mathrm{ml}$ & 230 \\
$\mathrm{ug} / \mathrm{ml}$ & $<5.5$ \\
$\mathrm{ug} / \mathrm{ml}$ & $<2.8$ \\
& 240 \\
& \\
&
\end{tabular}




$\begin{array}{lll}\text { Component } & \text { Units } & \text { Value } \\ \text { Gross Alpha } & \mathrm{Bq} / \mathrm{ml} & 20 \\ \text { Gross Beta } & \mathrm{Bq} / \mathrm{ml} & 5900 \\ \mathrm{Zr} & \mathrm{ug} / \mathrm{ml} & <5.5 \\ \mathrm{Sp} \mathrm{G} & & \mathrm{ND} \\ \mathrm{TS} & \mathrm{g} / \mathrm{L} & 765.5 \\ \mathrm{pH} & & \mathrm{ND}\end{array}$

* Nitric acid, 2000 gallons/year, neutralized with sodium hydroxide $(50 \%)$ solution, 440 gallons per year.

Table B-2

BETHEL VALLEY LIQUID LOW LEVEL WASTE

RADIONUCLIDE SOURCE TERM FOR TANK L-11

BUILDING 3544 - PROCESS WASTE TREATMENT PLANT

Component
Sr-90
Co-60
Cs-137
Eu-152
Eu-154
Eu-155
Ru-106
Zr/Nb-95

$\underline{\text { Units }}$

Ci/gal

$\mathrm{Ci} / \mathrm{gal}$

$\mathrm{Ci} / \mathrm{gal}$

$\mathrm{Ci} / \mathrm{gal}$

$\mathrm{Ci} / \mathrm{gal}$

$\mathrm{Ci} / \mathrm{gal}$

$\mathrm{Ci} / \mathrm{gal}$

$\mathrm{Ci} / \mathrm{gal}$
Value
.0156
.00052
.00229
.000624
.000166
.000104
.000208
.00104


Table B-3

MINIMUM CONCENTRATIONS OF RADIOACTIVE

CONTAMINANTS FOR DISCHARGE TO THE LLW TREATMENT SYSTEM

CONTAINMENT

CONCENTRATION $(\mathrm{Bq} / \mathrm{L})$

GROSS ALPHA

GROSS BETA

175

$\mathrm{Sr}-90$

Cs-137

Co-60

Eu-152

Eu-154

Eu-155

Ru-106

10,000

10,000

400

$185 *$

$740 *$

$740 *$

ZrNb-95

$3700^{*}$

$222^{*}$

$1480^{*}$

* DOE Order 5400.5 DCG values 
LLW which also contains toxic materials, PCB's, mercury, etc., should not be discharged to the LLW system (unless a waiver is granted by Waste Management Operations), but should be transferred to the Hazardous Waste Operations Group for storage until its ultimate disposition is determined. Organic solvents or organic chemicals contaminated with radioactivity may be discharged into LLW drains provided the primary hazard of concern is radioactivity. Sanitary waste must not be discharged to the LLW system unless a medical emergency exists.

No new LLW streams greater than $15 \mathrm{gpd}$ in volume are to be added without the permission of the Liquid Waste LCO.

IV.B.I(c) Corrosion Protection

The LLW transfer system modification for the Building 3544 facility does not expose the external shell of any metal tanks to direct contact with the soil or with water. As noted previously, the waste concentration tank is located in an aboveground, lined, concrete diked area. The new LLW transfer piping constitutes an important part of the modification. This piping is aboveground and is not in direct contact with a backfill material.

The outer (secondary) containment pipe of the double wall LLW pipe system utilizes a Type 304L stainless steel alloy to establish the principal corrosion control measure. A review of this system found that they are properly designed and meet all design criteria.

IV.B.I(d) Vehicular Traffic Protection

The upgrade being performed to Building 3544 involves the addition of an LLW transfer line within the building and extending above ground to a loading arm at the transfer station. The piping will not be subjected to surcharge loadings from vehicular traffic. 
IV.B. 1(e) Design Considerations

(i) The concentrated waste tank is housed in an aboveground vault with a diked structure.

The tank foundation consists of an 8 in. thick reinforced concrete vault base slab.

The tank foundation is on finished grade. The base slab is founded on compacted crushed stone fill which in turn is founded on rock. Due to the on-grade tank foundation, the net maximum bearing pressure on the rock is generally less than $1 \mathrm{ksf}$, well within the permissible bearing capacity of the rock. Due to the very low foundation bearing pressure relative to the rock bearing capacity, settlement of the tank is expected to be insignificant.

The assessment concludes that the tank foundation is conservatively designed to maintain the load of a full tank.

(ii) The concentrated waste tank design includes the provision of anchorage for the tank to the concrete structure. The anchorage has been evaluated for seismic loading assuming the tank is full (which is the controlling seismic condition). The anchorage has also been evaluated for the buoyancy effect resulting from the maximum probable flood, assuming a minimal inventory in the tank (thereby producing the maximum buoyancy forces).

Four integral supports are furnished at the bottom of the tank for vertical support. Each support rests on separate baseplates that are embedded in concrete above the base slab.

The loadings, load combinations, and permissibles used in the tank vault design comply with the 1973 Uniform Building Code for Seismic Zone 2. 
The maximum horizontal ground surface acceleration used in the evaluation of the tank system is based on current site spectra which is $0.32 \mathrm{~g}$. Since the tank is anchored to the base slab of the vault which is founded on rock, seismic loads for the design of the tank anchorage correspond to use of the peak value from the median centered Newmark and Hall response spectrum for a competent soil site (conservative assumption) anchored at $0.32 \mathrm{~g}$, assuming $5 \%$ equipment damping. The resulting peak horizontal acceleration is $0.68 \mathrm{~g}$. Directional components are combined by using the maximum response in one direction plus $40 \%$ of the maximum from the other two directions.

- The assessment concludes that the waste concentration tank is adequately anchored to prevent dislodgement due to the occurrence of postulated seismic events.

(iii) The tank foundation is founded on compacted crushed stone on rock. The average annual frost penetration, according to the Standard Building Code, is less than 10 inches for the ORNL. Therefore, frost heave will not affect the tank foundation.

\section{IV.B.2. Tank Systems Installation}

The procedure for handling double wall pipe and the connection to the concentrated waste tank, from the time of receipt on site, up to and including final fit-up and testing, will be reviewed by a qualified installation inspector. During fabrication and construction of the Tank System, primary inspection of welds in the tank, piping, liners, etc. will be performed by LMER AWS-Certified welding inspectors. Inspection of concrete, rebar, waterproofing, etc. will be performed by qualified LMES construction engineers. 
The installation inspector will observe the installation of the piping and will visually inspect the completed installation for the presence of weld breaks, punctures, scrapes of protective coatings, cracks, corrosion, or other structural damage or inadequate construction/installation. Design engineers from LMES and the Architect/Engineer (Gilbert/Commonwealth, Inc.) will consult with construction engineers, LMER QA personnel, and construction personnel, and will audit installation records to confirm compliance with design provisions.

The remainder of this section summarizes the measures that must be undertaken during the fabrication, installation, and testing of the LLW transfer system prior to placing the system in service. These measures are included in the technical specifications governing the design, fabrication, and installation of the LLW piping, and are presented in summary form in the following Installation Assessment Summary. 
INSTALLATION ASSESSMENT SUMMARY

\begin{tabular}{|c|c|c|}
\hline $\begin{array}{c}\text { Assessment Action } \\
\text { Required }\end{array}$ & By Whom & When \\
\hline $\begin{array}{l}\text { Inspect reinforcing steel } \\
\text { for grade, number, size, } \\
\text { spacing of bars; } \\
\text { adequacy of support ties, } \\
\text { splices; clearances to } \\
\text { formwork, subgrade, and } \\
\text { between bars; cleanliness }\end{array}$ & $\begin{array}{l}\text { LMES Construction } \\
\text { Engineer }\end{array}$ & $\begin{array}{l}\text { Prior to each concrete } \\
\text { placement }\end{array}$ \\
\hline $\begin{array}{l}\text { Review shop detail and } \\
\text { installation drawings for } \\
\text { stainless steel dike walls } \\
\text { and chemical resistant } \\
\text { liner }\end{array}$ & LMES Design Engineer & Prior to fabrication \\
\hline $\begin{array}{l}\text { Review qualification } \\
\text { certifications of } \\
\text { procedures and welders } \\
\text { to ASME Code Section IX } \\
\text { requirements for stainless } \\
\text { steel dike }\end{array}$ & $\begin{array}{l}\text { LMER Quality Dept. } \\
\text { (AWS Qualified Weld } \\
\text { Inspector) }\end{array}$ & $\begin{array}{l}\text { Prior to performance of } \\
\text { work }\end{array}$ \\
\hline $\begin{array}{l}\text { Review manufacturer } \\
\text { certification of chemical } \\
\text { resistant coating } \\
\text { applicator }\end{array}$ & LMES Design Engineer & $\begin{array}{l}\text { As part of acceptance of } \\
\text { proposed waterproofing } \\
\text { system }\end{array}$ \\
\hline $\begin{array}{l}\text { Certification of chemical } \\
\text { resistant adherence test } \\
\text { to concrete substrate }\end{array}$ & LMES Design Engineer & Prior to field installation \\
\hline $\begin{array}{l}\text { Review Certified Material } \\
\text { Test Reports submitted } \\
\text { by supplier of piping } \\
\text { materials for primary and } \\
\text { secondary piping and } \\
\text { dike liner materials }\end{array}$ & $\begin{array}{l}\text { LMER Quality Dept. } \\
\text { Personnel }\end{array}$ & $\begin{array}{l}\text { Upon receipt, prior to } \\
\text { fabrication and } \\
\text { installation of piping, } \\
\text { liners, etc. }\end{array}$ \\
\hline
\end{tabular}




\section{INSTALLATION ASSESSMENT SUMMARY}

\begin{tabular}{|c|c|c|}
\hline $\begin{array}{c}\text { Assessment Action } \\
\text { Required }\end{array}$ & By Whom & When \\
\hline $\begin{array}{l}\text { Review piping and vault } \\
\text { 'liner weld examination } \\
\text { records (required per } \\
\text { Tables B.3-1 and B.3-2) }\end{array}$ & $\begin{array}{l}\text { LMER Quality Dept. } \\
\text { Personnel }\end{array}$ & $\begin{array}{l}\text { Ongoing during } \\
\text { installation of piping and } \\
\text { vault liner. To be } \\
\text { complete prior to } \\
\text { conducting pressure test } \\
\text { for any segment of } \\
\text { piping. }\end{array}$ \\
\hline $\begin{array}{l}\text { Review piping pressure } \\
\text { test records (refer to } \\
\text { Section IV.B. } 5 \text { of this } \\
\text { assessment) }\end{array}$ & $\begin{array}{l}\text { LMER Quality Dept. } \\
\text { Personnel }\end{array}$ & $\begin{array}{l}\text { Following completion of } \\
\text { pressure test, prior to } \\
\text { covering pipe in pipe } \\
\text { trench or pouring } \\
\text { concrete (for embedded } \\
\text { pipe). May be } \\
\text { accomplished by } \\
\text { segment or portion of } \\
\text { piping system that can } \\
\text { be isolated }\end{array}$ \\
\hline $\begin{array}{l}\text { Conduct visual inspection } \\
\text { of the LLW pipe system, } \\
\text { dike and liner (inspect for } \\
\text { weld breaks, punctures, } \\
\text { cracks, corrosion or other } \\
\text { structural damage or } \\
\text { inadequate } \\
\text { construction/installation) }\end{array}$ & $\begin{array}{l}\text { LMER Quality } \\
\text { Department Personnel }\end{array}$ & $\begin{array}{l}\text { Prior to placing system } \\
\text { into service }\end{array}$ \\
\hline
\end{tabular}


INSTALLATION ASSESSMENT SUMMARY

\begin{tabular}{|c|c|c|}
\hline $\begin{array}{c}\text { Assessment Action } \\
\text { Required }\end{array}$ & By Whom & When \\
\hline $\begin{array}{l}\text { Witness or review } \\
\text { documented results of } \\
\text { functional testing for } \\
\text { Tank System support } \\
\text { equipment, including: } \\
\text { - Level instrumentation } \\
\text { in sumps and tanks } \\
\text { - Pressure } \\
\text { instrumentation for } \\
\text { double contained } \\
\text { piping annular space } \\
\text { Transfer Pump and } \\
\text { System Functional } \\
\text { Testing to assure } \\
\text { leak-tight operation of } \\
\text { pump seals, valve } \\
\text { stem piping and } \\
\text { piping flanges }\end{array}$ & LMES Design Engineer & $\begin{array}{l}\text { Prior to placing Tank } \\
\text { System into } \\
\text { contaminated service }\end{array}$ \\
\hline
\end{tabular}

\section{IV.B.3. Inspection Reports}

The installation of the Building 3544 LLW transfer piping utilizes a comprehensive and stringent set of inspections to assure the leaktight integrity of the System, following installation. These include inspections of shop and field welds in LLW primary and secondary piping, in accordance with Table B.3-1. The existing waste concentration tank has been designed and fabricated in accordance with the ASME Boiler and Pressure Vessel Code, Section VIII, Div. 1 to the extent that it applies. This code requires qualified and documented weld examination procedures. The installation assessment will include reviews of weld examination records, leak test records, material certifications, and on-site walkdowns and visual inspections of essential portions of the LLW transfer system. 
The weld examinations noted above, in conjunction with a thorough visual examination of the entire system, provide assurance that potential weld breaks, punctures, cracks, and corrosion will be detected and remedial work undertaken prior to closure of the system. Welding inspectors shall be certified by AWS QC-1.

LMES will maintain a retrievable file of inspection reports, test records, and other pertinent documentation. These reports, records, etc. will be reviewed, on a statistical sample basis, by the Installation Assessment team, to assure that acceptable welds have been produced. 
TABLE B.3-1

WELD INSPECTION SUMMARY

\begin{tabular}{|l|l|c|c|c||}
\hline Number & Title & $\begin{array}{c}\text { Visual } \\
(1)\end{array}$ & $\begin{array}{c}100 \% \\
\text { Radiography } \\
(2)\end{array}$ & $\begin{array}{c}\text { Dye Pen } \\
\text { Last Pass } \\
(3)\end{array}$ \\
\hline $\begin{array}{l}\text { Section 18100 } \\
(3.07)(A)(1)\end{array}$ & Stainless Steel Dike & $\mathrm{X}$ & $\mathrm{X}$ & \\
\hline $\begin{array}{l}\text { Section 18100 } \\
(3.08)(\mathrm{A})(2)\end{array}$ & $\begin{array}{l}\text { Outer Pipe for LLW System } \\
:\end{array}$ & $\mathrm{X}$ & $(4)$ & $\mathrm{X}$ \\
\hline $\begin{array}{l}\text { Section 18100 } \\
\text { (3.08)(A)(4) }\end{array}$ & $\begin{array}{l}\text { Stainless Steel Systems - } \\
\text { High Quality (Inner Pipe) }\end{array}$ & $\mathrm{X}$ & $\mathrm{X}$ & $\mathrm{X}$ \\
\hline $\begin{array}{l}\text { Section 18100 } \\
\text { (3.08)(A)(4) }\end{array}$ & Field Welds & $\mathrm{X}$ & $\mathrm{X}$ & $\mathrm{X}$ \\
\hline
\end{tabular}

NOTES: (1) Visual inspection to be in accordance with ASME B31.3, para 341.4.1(a)

(2) Radiographic examination to be in accordance with ASME B31.3, para. 344.5

(3) Dye Penetrant Examination to be in accordance with ASME B31.3, para. 344.4

(4) Random (5\% min.) 


\begin{abstract}
IV.B.4. Backfilling
There is no backfilling required to be provided for this modification.

IV.B.5. Testing

The pressure containing boundary of the primary and secondary piping is tested for leak tightness prior to being placed in service. The leak tests are either pneumatic or hydrostatic tests, conducted in accordance with applicable LMES specifications. The modification does not affect the pressure boundary integrity of the existing waste concentration tank. Pressure testing of the tank is therefore not within the scope of this document. These test requirements are noted in the Installation Assessment Summary and are summarized below:
\end{abstract}

\title{
Leak Testing Requirements
}

\begin{tabular}{|c|c|c|c|}
\hline $\begin{array}{l}\text { System/Component } \\
\text { Primary Pipe } \\
\text { Secondary Pipe }\end{array}$ & $\begin{array}{l}\text { Type of Test/Media } \\
\text { Pneumatic/Nitrogen } \\
\text { Pneumatic/Nitrogen }\end{array}$ & $\begin{array}{l}\text { Code } \\
\text { B31.3 } \\
\text { B31.3 }\end{array}$ & $\begin{array}{l}\text { Spec Reference } \\
15073 \\
15073\end{array}$ \\
\hline
\end{tabular}

These test reports will be reviewed by the Installation Assessment Team to assure that leak-tight construction has been provided.

\section{IV.B.6. Ancillary Equipment Protection}

The methods implemented to properly support and protect ancillary equipment against physical damage and excessive stress due to settlement, vibration, expansion, or contraction are described herein. The methods used may be divided into three categories as applicable to double wall piping systems; single wall piping systems within a lined, seismically designed structure; and a tank (single wall) within a lined, seismically designed structure.

The double wall piping is routed outside of the diked area and through the building wall to the truck loading area. The piping is supported for dead weight. Where appropriate, additional restraint are provided for lateral forces that may be induced by seismic or wind conditions. 
The waste piping system above the tank vault floor has been analyzed for the various loading conditions that may apply, including: (1) potential settlement of structures at which the piping system terminates or is anchored; and (2) seismic loadings induced by the design basis seismic event. The stresses induced in the piping system (primary and secondary pipe) are within ANSI B31.3 code allowable values for the applied loadings.

The single wall waste piping routed within the lined structure is supported for dead weight. Where appropriate, additional restraints are provided for lateral forces that may be induced by hydraulic conditions. Seismic restraint is not required since the piping is contained within a lined, seismically qualified Secondary Containment structure. It should be noted that the basic design inherently provides a significant degree of seismic event resistance since most runs of piping in this category are relatively short and stiff. Also, the seismic accelerations are modest because the vault structures are below grade and are themselves relatively rigid. (Amplification of seismic inputs due to structural response is minimal.)

The tank support is embedded in concrete on the tank vault floor. The tank support and concrete embedment are designed to withstand uplift and pullout forces caused by either seismic or buoyancy loadings.

This assessment concludes that the design has incorporated adequate provisions for the protection of ancillary equipment against physical damage and excessive stress. The installation will be assessed in accordance with the requirements presented in the Installation Assessment Summary, Section IV.B.2 of this assessment.

\section{IV.B.7. Corrosion Protection}

A review of the pertinent drawings and specifications was performed to ensure that necessary corrosion protection recommendations were incorporated. The results of this review found that design recommendations have been properly incorporated.

This assessment concludes that the design incorporates an appropriate type and degree of corrosion protection for the above ground piping. 
IV.B.8. Corrosion Expert

There is no cathodic protection required for the scope of this modification, therefore no corrosion expert will be utilized.

IV.B.9. Documentation

This section contains written statements by those persons required to certify the design of the LLW transfer system and supervise the installation of the LLW piping. Separate statements are provided, one covering the design of the LLW transfer system, the other covering the installation of the LLW transfer system (Exhibits B.9-1 and B.9-2).

The installation certification will be signed and stamped following the completion of the installation and a review of pertinent records documenting required non-destructive examinations, inspections, repairs, and tests. These activities are described in Sections IV.B.2 through and including IV.B.7 of this assessment.

Suitable retrievable permanent records of the results of the aforementioned non-destructive examinations, inspections, repairs, and tests will be maintained by Lockheed Martin Energy Systems. These records will be reviewed by the person who will, in the future, certify the installation. 


\section{DESIGN CERTIFICATION}

This statement certifies that the LLW transfer system providing collection, storage, and transfer of spent process fluid to the outside truck loading station for the Process Waste Treatment Plant (Building 3544) is properly designed, and the design is in accordance with the applicable requirements of the Federal Facility Agreement, Docket No. 89-04-FF, covering the Oak Ridge Reservation.

This statement applies to the design of the LLW transfer system and to the provisions specified by the design (examinations, inspections, tests) that must be executed during installation, including the conduct of any repairs that may be required during installation. A separate statement must be prepared and certified, following the installation of the LLW transfer system, to attest that the final installation is in compliance with the design and with provisions of the Federal Facility Agreement, Docket No. 89-04-FF.

I, the undersigned, certify that this document was prepared under my direction by qualified personnel who had complete access to pertinent design information. Based on my inquiry of those persons directly responsible for gathering and evaluating the information, the information submitted is, to the best of my knowledge and belief, true, accurate, and complete.

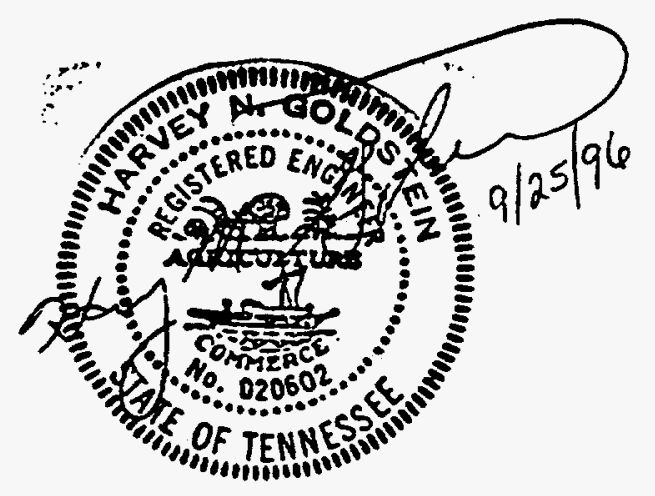


Reserved for Exhibit B.9-2 - Installation Certification

(Please note format used for Design Certification) 


\section{IV.C. Standards for Containment/Release Detection}

The secondary containment systems consist of (1) an outer pipe completely enveloping the primary, inner pipe; (2) a single pipe within a lined, seismically designed, reinforced concrete above ground vault containing the waste concentration tank and (3) a lined transfer station.

The release detection system for the double contained piping system utilizes nitrogen pressure maintained in the annular space between the inner and outer pipes, with continuous pressure monitoring. The release detection system for the tank system utilizes a sump at a low point in the liner/vault structure. The sump to which the concentrated waste tank drains is lined with type $304 \mathrm{~L}$ stainless steel.

\section{IV.C.1. Secondary Containment Systems Requirements}

\section{(a) Construction Compatibility}

The Type 304L stainless steel secondary pipe is fully capable of containing substances that may potentially leak from the primary transfer line from the concentrated waste tank to the truck loading arm. The waste substances that are transferred via this line may include a variety of dilute acids, bases and organics. The residence time for the acids is low and will be neutralized with a high $\mathrm{pH}$ solution and flushed with water. The flanged connections in the waste piping are located within the vault structure.

The existing secondary containment surface material for the concentrated waste tank (i.e., the vault liner), which could be exposed to process fluid, assuming leakage through the primary containment, is provided with a 40mil-thick system of Quantum Polymorphic Resin. The walls of the vault are provided with a three-coat system of Americoat 66 epoxy. According to manufacturers specifications, the vault floor resin coating and the vault wall epoxy coating is compatible with the process streams or other substances placed in the Tank System and designed to prevent migration of waste into the concrete. In addition, this modification includes the addition of a diked area around the concentrated waste tank. This area will be lined with a chemical resistant coating. The material is to be Ceilcrete 695 which is a glass reinforced 
system consisting of a primer, basecoat, saturant and top coat.

The secondary containment surface material for the transfer station, which could be exposed to process fluid during the loading operation is provided with a chemical resistant coating. The material is Ceilcrete 695 which is a glass reinforced system consisting of a primer, basecoat, saturant and top coat. According to manufacturers specifications, the transfer station floor and wall coating is compatible with the process streams or other substances placed in the Tank System and designed to prevent migration of waste into the concrete.

(b) Containment Systems Foundation

The secondary containment system foundation for Building 3544 consists of the 8 in. thick reinforced concrete vault base slab.

The Building 3544 tank vault is a rigid reinforced concrete structure. This structure is founded on a layer of compacted crushed stone fill which is founded on rock.

Due to the rigid nature of the structure and the foundation bearing on rock, the potential for bearing failure and/or settlement are negligible. The vault is above ground and the vault structural stability has been checked to assure that the dead weight of the structure conservatively exceeds an assumed buoyancy force due to flooding. For purposes of evaluation, the flood water level was conservatively assumed to be 5 feet above the base slab. This corresponds to a 2,000 year flood which is in excess of the performance requirements for the design basis flood for a Performance Category 1 structure as outlined on DOE-STD-1020-94.

The vault base slab has been designed assuming a rigid slab model continuously supported by the soil. The walls of the tank vault have been designed for a wind loading of 
20 psf which will produce an overturning moment that is more limiting than the resulting flood hydrostatic pressure loading.

The dike, reinforced concrete tank vault walls and base slab and the transfer station have been conservatively designed for appropriate loadings including pressures due to surcharge, seismic and hydrostatic loadings.

Wind design basis loads that were used to evaluate Building 3544 include wind pressure and atmosphere pressure change. Tornado and missile design consideration is not applicable to Performance Category 1 and 2 facilities.

This assessment concludes that the containment systems foundation has the capability to provide support to the secondary containment system without failure and is designed for the appropriate loading conditions.

\section{(c) Leak Detection System}

The secondary containment system's leak detection provisions are divided into three approaches:

(i) Double Wall Piping Annulus Leak Detection

The annular space in the double wall piping system is pressurized with nitrogen. The piping run is partitioned by barrier plates on either end of the double contained pipe constituting an independent pressure boundary.

The system configuration, for the double wall service lines conveying waste from Building 3544 to the truck loading arm, partitions the run of pipe into an independent pressure boundary. The annular space is pressurized with nitrogen. Pressure monitoring for this line utilizes a pressure transmitter serving the pipe segment and monitored in the control room. If a potential leak is detected, by decrease of annular space pressure, the leak location may be determined and sequentially isolating the segment of the line. 
The assessment concludes that the aforementioned leak detection system for the annular space of the double wall piping system is capable of detecting virtually all leaks within considerably less than 24 hours.

(ii) Tank Leak Detection System

The detection of leaks from the concentrated waste tank in the vault is based on operator surveillance on a daily basis. Any leakage from the tank would flow by gravity to the diked area containing the plug in the floor drain. Liquids would accumulate in the diked area and would be readily visible by operators present in Building 3544. The time period required for this accumulation of liquid will vary inversely with the rate of a potential leak (i.e., the larger the leak, the shorter will be the time interval required to detect the leak).

The total quantity of a non-detected leak represents a very small fraction of the minimum rated tank capacity (500 gallons), and is contained by the diked area. The assessment concludes, therefore, that extremely small leaks, even if not detected within 24 hours, will be detected at the earliest practical time.

(iii) Transfer Station Leak Detection System

The detection of leaks from the LLW transfer piping and loading arm in the transfer station is based on the provision of administrative control and constant supervision during loading operations. Any leakage from the transfer pipe or loading arm will be detected by an operator at the transfer station during loading operations. The transfer station is equipped with a "kill" switch which will shut off the transfer pump. The time period required for any accumulation of liquid will vary inversely with the rate of a potential leak (i.e., the larger the leak, the shorter will be the time interval required to detect the leak and terminate the transfer operationl. 
The total quantity of a non-detected leak represents a very small fraction of the minimum rated tank capacity ( 500 gallons), and is contained by the transfer station sump liner. The assessment concludes, therefore, that extremely small leaks will be detected at the earliest practical time.

\section{(d) Drainage and Liquid Removal}

The secondary containment systems are designed to permit removal of accumulated liquids arising from leaks, spills, or condensation within the secondary containment volumetric envelope.

(i) Double Wall Piping Annulus Liquid Removal

The double wall piping is sloped to a low point at either of its ends. A drain nipple is provided at the intermediate low points, with connecting tubing routed to a connecting point from which accumulations of liquids arising from potential leaks maybe removed. The annular space drain points are accessible. Leaked substances may be removed in the length of time required to detect a leak and gain access to the drain nipple.

Additional connections are provided to the annular space for venting and/or injection of a flushing liquid, if required.

The as-constructed plan and profile of the piping will be reviewed during the installation assessment to assure that the design provisions for liquid removal capability are not compromised. Deviations in plan and profile during construction of the pipelines must have engineering approval prior to final placement of the piping.

\section{(ii) Tank Vault Liquid Removal}

The tank vault and diked area containing the concentrated waste tank is provided with a sloped floor to a drain with a sump of approximately 1150 
gallons net capacity. The floor drain within the confines of the diked area is equipped with a plug that will be removed pending waste characterization of any spillage. Process liquids will be introduced through the floor drain sump provided and removed by the pumping system. Any LLW will be removed from the diked area by hand pumps.

(iii) Single Wall Piping Liquid Removal

The single wall waste piping within the confines of Building 3544 is provided with secondary containment by the chemical resistant liner of the vault and diked area. Leaking liquids are captured and contained by the diked area pending waste characterization. Process liquids will be introduced through the floor drain sump provided and removed by the pumping system. Any LLW will be removed from the diked area by hand pumps.

\section{(e) Secondary Containment for Tanks}

The secondary containment system for the concentrated waste tank consists of a chemical resistant liner external to the tank. The liner is continuous so that it forms a leak-tight containment system for liquids. The liner is bonded to the inner surface of the reinforced concrete vault. The vault structure is designed to withstand specific, defined loading conditions, as described in paragraph IV.B.I.(e) of this assessment.

The Building 3544 LLW transfer system, therefore, is provided with two specific features, integrated into a secondary containment system, which provide a high degree of environmental protection against leaks or spills from the primary containment vessel.

(f) Additional Requirements

(i) External Liner Systems

The design of this tank System does not utilize an external liner to achieve compliance with the 
applicable Federal Facility Agreement requirements. However, water proofing is provided on the outside of the vault structure described below. The function of this waterproofing is discussed in (ii)(D), below.

(ii) Vault Systems

\section{(A) Capacity}

The Building 3544 tank vault is provided with a chemical resistant liner, from and including the floor of the vault, up to a height of 8 in. (nominal) above the floor within the diked area. This provides a gross volume of approximately 650 gallons, compared to the tank volume of approximately 500 gallons. The lined vault system, therefore, provides a margin of safety in capacity in excess of the volume of the tank contained within the vault.

(B) Run-on or Infiltration Prevention

Surface water drainage is directed around and away from the Building 3544 tank vault by means of site grading. Existing site topographic relief will prevent the build-up of surface water during storm/rainfall events. The tank vault finished floor elevation is $782^{\prime} 6 "$ ", which is 6" above the ground elevation and includes a foundation drain system. The use of a waterproofing system minimizes the potential for infiltration of groundwater into the vault.

The design of the surface water drainage is combined with the characteristics of the vault subsurface design to prevent surface run-off from entering the vault. The reinforced concrete tank vault walls and the external waterproofing system also will protect the tank from run-on and infiltration effects. 
The vault system has been provided with redundant design features to prevent run-on or infiltration of precipitation into the secondary containment system.

The reinforced concrete vault structure meets applicable requirements of $A C l 350 R$ for concrete sanitary engineering structures, including reinforcing ratios and bar spacing as well as concrete quality.

\section{Water Stops}

The Tank L-11 secondary containment structure is constructed with 2 " $\times 4$ " keyways with continuous water stops in all below-grade construction joints. The design drawings and construction specification do not indicate that the water stops are chemical resistant, however. A review of the issue concludes that it is unlikely that either water from outside the system or LLW from inside the system will come in contact with the water stops since the vault is externally waterproofed, internally coated and provided with an alarmed leak detection and removal system.

\section{(2) Coating or Lining}

The interior of the concrete vault is provided with a 40 mil-thick system of Quantum Polymorphic Resin lining that is compatible with the stored waste and will prevent the migration of waste into the concrete. A continuous chemical resistant liner is bonded to the interior surface of the vault base slab and walls. This liner provides the leak-tight barrier to contain more than $100 \%$ of the tank volume (see Paragraph IV.C.I.(f)(ii)(A). The 
remainder of the interior surfaces of the tank vaults above the liner is coated with an impermeable epoxy coating system that will prevent migration of any liquid through it into the concrete.

(C) Vapor Protection

The concentrated waste tank is provided with a tank offgas system (primary system) and a vault space ventilation system (secondary system). The tank is vented through a HEPAfiltered tank offgas system that keeps the tank under negative pressure relative to the vault pressure. The existing tank vault is ventilated with a HEPA-filtered vault exhaust ventilation system that generated a sweep flow rate of approximately 1700 CFM through the vault. This exhaust system was designed to maintain the vault at a negative pressure.

(D) Moisture Migration

The existing reinforced concrete tank vault structure is above ground. The groundwater level was determined to be approximately 5 feet below grade. While groundwater levels are below the base slab level, a vapor and water barrier was provided under the base slab and exterior walls. The vapor and water barrier system consists of a semi-rigid membrane asphalt core board.

The vapor and water barrier envelopes the exterior surfaces of the vault, including under the base slab and along the walls. Finished grade around the vault is sloped to channel surface run-off away from the vault.

It is concluded that the provision of the external waterproofing system will prevent migration of moisture into the vaults. 
(iii) Double Contained Tanks

Not applicable to the scope of this upgrade.

\section{(iv) Support Equipment}

Support equipment is provided with secondary containment that meets the requirements stated previously in this section (IV.C.) except for single contained above ground piping which is visually accessible on a daily basis. These piping segments are located in specific areas within Building 3544 above the vault and in the vicinity of the waste concentration tank. Other items of support equipment and their secondary containment features are noted below.

- $\quad$ Piping is provided with double containment construction, the outer pipe constituting the secondary boundary. Leak detection and a means of removal of accumulated leakage are provided for the annular spaces between the primary and secondary pipes.

- A pumping system is used to pump fluid out of the lined vault sump; should any such fluid accumulate in the sump.

- The single wall piping at the truck loading station is provided with a secondary containment comprised of a concrete pad, a chemically resistant liner and a sump. Leak detection is accomplished by direct surveillance of the operator, who is provided. with a manual switch that terminates pumping operations. This portion of the single wall LLW piping is filled with liquid only during transfer operation. The line is drained back to the tank when the transfer operation is terminated.

- The design of this facility does not employ sealless or magnetic coupling pumps and sealless valves that require inspection on a 
daily basis. However, the above grade waste concentration transfer pump and piping should be visually inspected on a daily basis to confirm that unacceptable leakage is not occurring.

- $\quad$ The design of this facility employs pressurized aboveground piping systems with administrative controls to shut-off liquid waste transfer operations.

In summary, this assessment concludes that support equipment is provided with acceptable secondary containment provisions, including leak detection and means for removal of accumulated liquids, as applicable.

\section{CONCLUSION}

This assessment concludes that the completed design for the new LLW transfer piping for the building 3544 Process Waste Treatment Plant meets the applicable requirements of the Federal Facility Agreement, Docket No. 89-04-FF.

- The waste concentration tank and primary (inner) piping are specified to the appropriate codes and with the appropriate materials to provide satisfactory longevity in the intended service. The specifications require appropriate materials properties, weld examination and inspection, testing, and final visual inspections to assure leak tight integrity.

- Secondary containment features are provided for Tank L-11 and associated transfer piping. Leak detection within the diked area inside the structure and at the truck loading station is accomplished by direct operator surveillance. The vault structure has been evaluated for the applicable loadings and load combinations for low hazard category structures, including loadings associated with postulated seismic, flood and wind occurrences. Appropriate materials, fabrication and installation techniques, examinations and inspections have been specified to assure that the required quality and integrity of the design is achieved during construction.

The piping is fabricated from 304L stainless steel which will provide corrosion control that projects a useful life span in excess of the planned operational life of the system. 
- The civil and geotechnical engineering design provides a satisfactory approach to the overall integrity of the Tank System and is based upon site, subsurface, and pipe backfill data provided by the Government to the Architect/Engineer. Project construction drawings and technical specifications provide requirements, tests, and approvals necessary to assure a successful installation.

- $\quad$ Support equipment is protected against physical damage and excessive stress due to vibration, settlement, and expansion or contraction.

Secondary containment is provided for ancillary equipment, meeting the same standards as for the concentrated waste tank. Leak detection for the new diked area will rely on administrative controls which will involve daily inspections of the area.

The installation assessment, to be performed during installation and prior to commissioning of the system, is to confirm that design provisions have been correctly implemented. The Installation Assessment Team will review pertinent test and inspection records, and perform visual inspections, walkdowns, and witness functional tests to achieve this objective. An installation certification is to be prepared and inserted in Section IV.B.9 of this document. 


\section{DISTRIBUTION}

1. L. V. Asplund

2. W. R. Clark

3. R. A. Dean

4-6. J. T. Etheridge

7. H. R. Gaddis

8. R. E. Helms

9. L. L. Kaiser

10-12. D. M. Matteo

13-29. D. A. May

30. C. E. Mulkey

31. P. T. Owen

32. M. R. Peet

33. P. A. Schrandt

34. C. B. Scott

35. R. C. Stewart

36. M. L. Whitehead

37. Central Research Library

38. ER Document Management Center-RC

39. B. A. Skokan, Remediation Project Engineer, U.S. Department of Energy, Cloverleaf Building, Room 2165, 19901 Germantown Road, Germantown MD 20874

40. J. W. Wagoner II, Supervisory Remediation Project Engineer, U.S. Department of Energy, Cloverleaf Building, Room 2163, 19901 Germantown Road, Germantown, MD 20874

41. R. C. Sleeman, Director, Environmental Restoration Division, DOE Oak Ridge Operations Office, P.O. Box 2001, Oak Ridge, TN 37831-8541

42. M. Singleton, H\&R Technical Associates, Inc., P.O. Box 4159, Oak Ridge, TN 37831-4159 